\title{
IBM PENGRAJIN GULA MERAH DESA TANJUNG BAIK BUDI KECAMATAN MATAN HILIR UTARA KETAPANG
}

\author{
Nenengsih Verawati ${ }^{\# 1}$, Nur Aida*2, Khairul Muttaqin\#3 \\ \#1Program Studi Teknologi Pengolahan Hasil Perkebunan, Politeknik Negeri Ketapang \\ \#3Program Studi Teknik Pertambangan, Politeknik Negeri Ketapang \\ Jl. Rangga-Sentap Dalong, Sukaharja, Kota Ketapang \\ 1email.nenengerman@yahoo.com \\ \#2Program Studi Perancangan Jalan dan Jembatan, Politeknik Negeri Ketapang \\ Jl. Rangga-Sentap Dalong, Sukaharja, Kota Ketapang \\ 2email.nhuraidha@gmail.com
}

\begin{abstract}
ABSTRAK
Desa Tanjung Baik Budi memiliki lahan yang sangat berpotensi terutama dalam bidang perkebunan kelapa yang semuanya tersebar diberbagai dusun yang ada di Desa Tanjung Baik Budi. Tujuan dari Program Pengabdian Kepada Masyarakatan ini adalah: meningkatkan keterampilan masyarakat pengrajin gula kelapa dalam meningkatkan sistem produksi menjadi lebih baik untuk meningkatkan kualitas dan kuantitas gula kepala, memberikan motivasi dalam membangun jiwa berwirausaha yang mandiri, memberikan bantuan berupa peralatan, pelatihan dalam menghasilkan produk yang lebih baik dan baru yaitu pembuatan gula semut, memperbaiki sistem pengolahan, pengemasan, sanitasi dan pemasaran produk gula kelapa. Metode Progam Pengabdian Kepada Masyarakat yang dipakai untuk mencapai tujuan yaitu, melakukan sosialisasi program bisnis gula semut dan keuntungan bisnis ini kepada mitra binaan, memberikan pelatihan atau workshop tentang teknologi proses pembuatan gula yang lebih baik dan pelatihan tentang pembuatan gula semut serta proses pengemasan produk, mempersiapkan peralatan dan sarana penunjang lainnya selain dimiliki oleh mitra binaan, memberikan praktek kepada mitra tentang pembuatan gula semut, pengemasan produk serta teknik pemasaran. Hasil yang diperoleh dari kegiatan pengabdian kepada masyarakat oleh kedua mitra yaitu semua peserta dapat mengetahui ilmu baru terutama teknologi pembuatan gula semut, sehingga petani kelapa dapat memanfaatkan nira kelapa dalam pembuatan gula semut dan memiliki nilai jual yang tinggi.
\end{abstract}

Keywords - Gula cetak, gula semut dan nira.

\section{PENDAHULUAN}

Desa Tanjung Baik Budi memiliki lahan yang sangat berpotensi terutama dalam bidang perkebunan kelapa, sehingga banyak lahan-lahan potensial yang dimanfaatkan untuk budidaya pertanian maupun perkebunan dari tanaman padi, karet, dan kelapa semuanya tersebar diberbagai dusun yang ada di Desa Tanjung Baik Budi. Melihat potensinya yang begitu besar, Desa Tanjung Baik Budi memiliki komoditas tanaman kelapa. Tanaman Kelapa yang tumbuh di Desa Tanjung Baik Budi merupakan jenis kelapa lokal yang sudah lama tumbuh di sekitar masyarakat.
Desa Tanjung Baik Budi kurang lebih ada sekitar 50\% pengrajin gula kelapa yang masih memproduksi gula kelapa skala rumah tangga dengan asumsi rendah setiap hari mampu menghasilkan 7-10 kg gula kelapa. Pengrajin gula kelapa masih belum mampu meningkatkan kesejahteraan mereka. Hal ini dikarenakan gula kelapa yang mereka produksi selalu tidak menghasilkan nilai ekonomis yang tinggi, kurangnya modal untuk membeli peralatan pengolahan nira menjadi gula kelapa sehingga tidak semua nira yang disadap dalam waktu yang cepat dapat dibuat menjadi gula kelapa, alat mencetak gula yang masih menggunakan wadah bekas sabun cuci dan pengemasan masih secara 
manual sehingga mempengaruhi daya saing pasaran.

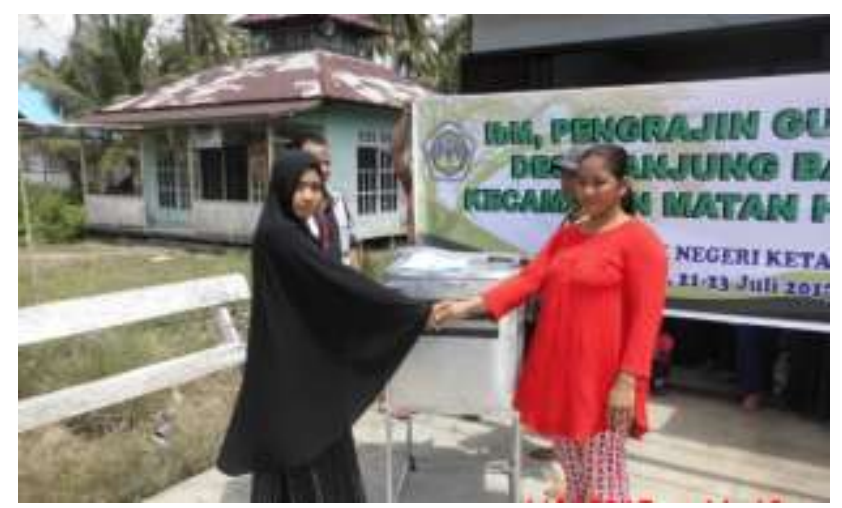

Gambar 1. Dokumentasi kegiatan

\section{TARGET DAN LUARAN}

Adapun target yang dilakukan oleh tim pengabdian kepada masyarakat tersebut meliputi beberapa rangkaian kegiatan yang akan dilaksanakan yaitu:

1. Sosialisasi program bisnis gula semut dan keuntungan bisnis ini kepada mitra binaan.

2. Memberikan pelatihan atau workshop tentang teknologi proses pembuatan gula yang lebih baik dan pelatihan tentang pembuatan gula semut serta proses pengemasan produk.

3. Mempersiapkan peralatan dan sarana penunjang lainnya selain dimiliki oleh mitra binaan.

4. Memberikan praktek kepada mitra tentang pembuatan gula semut, pengemasan produk serta teknik pemasaran.

5. Melakukan monitoring dan evaluasi pada mitra binaan terkait dengan perubahan atau hasil yang diperoleh setelah program IbM ini dilaksanakan.

6. Melakukan tindakan yaitu mendampingi mitra secara langsung untuk memasarkan produk baik di wilayah setempat sampai ke kota kabupaten.

Indikator keberhasilan suatu kegiatan adalah adanya perubahan antara sebelum diadakan kegiatan pengabdian masyarakat dan sesudah adanya kegiatan. Berdasarkan hal tersebut maka target luaran kegiatan yang dicapai pada pelaksanaan program ini adalah:

1. Kapasitas sumber daya manusia yang meningkat dalam hal ilmu pengetahuan dan wawasan untuk lebih berinovasi menghasilkan produk baru.

2. Metode pengolahan nira kelapa yang bentuknya menjadi gula berbentuk halus dan berharga lebih mahal serta mempunyai umur simpan yang lebih lama.

3. Proses pembuatan gula lebih efisien dan efektif dengan menggunakan perlatan yang lebih baik.

4. Sosial ekonomi masyarakat dalam hal pendapatan pengrajin gula kelapa semakin meningkat dan dihasilkannya produk baru yaitu gula semut.

\section{METODE PELAKSANAAN}

A. Alat dan Bahan yang digunakan

Adapun alat yang digunakan untuk menunjang kegiatan ini adalah sebagai berikut:

- Katalisator gula

- Oven pengering gula

- Baskom

- Cetakan

- Plastic pengemas

- Alat pengemas

\section{B. Rancangan Kegiatan}

Kegiatan pembuatan gula semut dan gula cetak. Pembuatan gula semut meliputi persiapan penyadapan nira pada jam 6 pagi, kemudian disaring, ditambah kayu raru, dimasukkan ke dalam alat katalisator gula, dimasak hingga mengental, dikeluarkan, didinginkan, dihancurkan dengan blender, diayak, dikemas. Sedangkan pada gula cetak yaitu nira disadap pada jam 6 pagi, disaring, dimasukkan ke dalam alat katalisator, dimasak sampai mengental, keluarkan, masukkan ke dalam cetakan gula,dinginkan, keluarkan dari cetakan, gula siap dikemas. 


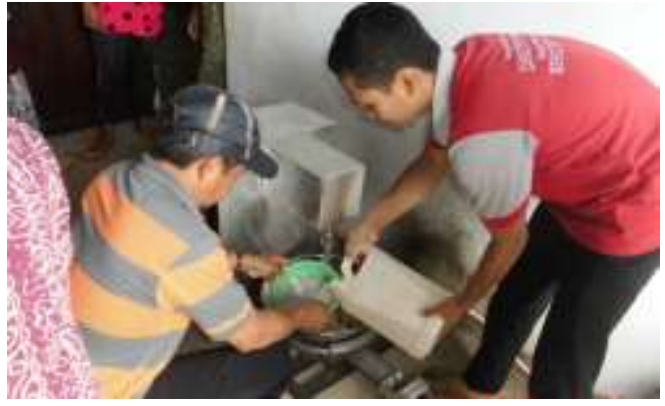

Gambar 2. Penyaringan nira

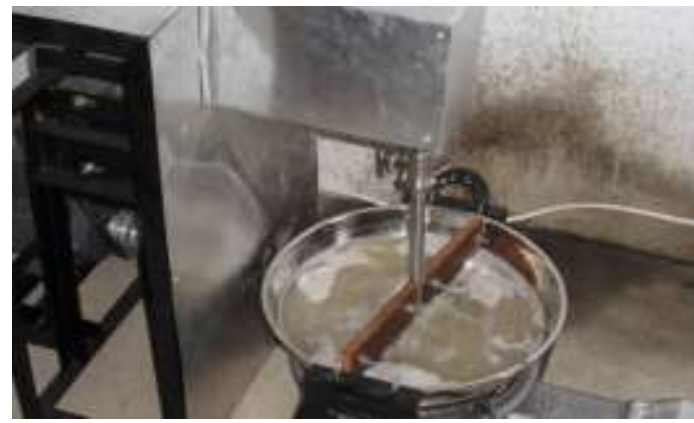

Gambar 3. Pemasakan nira

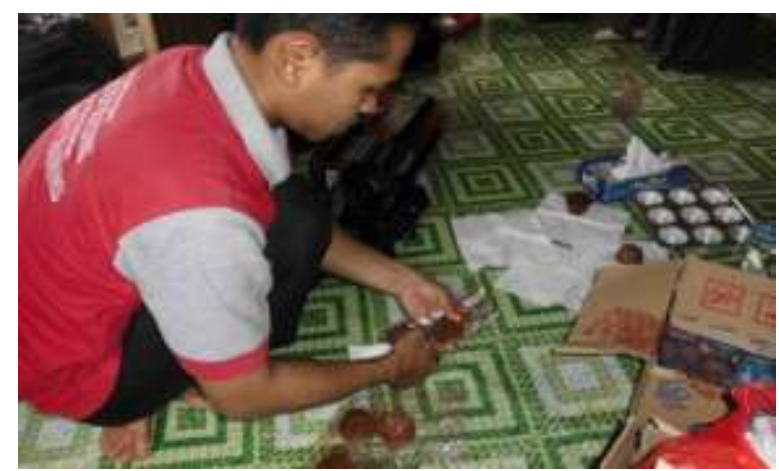

Gambar 4. Pengemasan gula

\section{Metode Pelaksanaan}

- Memberikan pelatihan dan praktek tentang produksi gula kelapa yang sesuai standar.

- Memberikan ilmu pengetahuan tentang kualitas produksi gula yang baik serta sosialisi akan pentingnya sanitasi dalam proses pengolahan makanan yaitu ruangan proses produksi, peralatan maupun ruangan penyimpanan produk akhir.

- Mengenalkan pada mitra tentang teknologi pembuatan gula yang lebih higienis dan efisien.

- Pendekatan kepada mitra dalam bentuk pelatihan/praktek tentang pembuatan gula semut serta memberikan bantuan berupa peralatan produksi yang memadai untuk pembuatan gula semut dan gula kelapa.

- Mendampingi mitra binaan dalam membuat label dan nama produk sehingga produk tersebut dapat dikenali oleh masyarakat.

- Mendampingi mitra untuk mempelajari sistem pengemasan yang baik untuk produk makanan agar produk tersebut bisa tahan lama dan tidak mudah rusak.

\section{HASIL DAN LUARAN YANG DICAPAI}

- Petani kelapa mulai meningkatkan penyadapan nira untuk bahan baku pembuatan gula cetak dan gula semut

- Adannya peningkatan penghasilan bagi petani kelapa dan pencetak gula

- Terbentuknya kerjasama yang baik tim mitra dalam hal pemasaran serta proses produksi gula cetak dan gula semut

- Masyarakat mulai mengenal dan menggunakan gula semut sehingga penjualan mulai terjadi peningkatan setelah 2 bulan diadakan pelatihan.

- Khususnya mitra pengrajin gula semakin baik dalam pembuatan gula semut.

Adapun rencana tahapan IbM berikutnya adalah:

- Pengembangan budidaya kelapa yaitu varietas Genjah khususnya didaerah pesisir kabupaten ketapang sehingga lebih mudah dipanjat karena pohonnya lebih pendek dan batangnya kecil.

- Peningkatan tanaman kelapa dengan varietas baru diharapkan dapat meningkatan kesdiaan bahan baku untuk beberapa tahun kedepannya.

- Meningkatkan produksi terutama gula cetak dan gula semut dari industri rumah tangga mejadi home industri.

- Mengadakan pelatihan untuk peningkatan SDM khususnya bidang pangan pada kedua mitra.

- Meningkatkan pemasaran ke berbagai daerah khususnya diluar Kabupaten Ketapang. 
- Melatih pengembangan produk-produk baru pada kedua mitra khususnya hasil perkebunan dan pertanian pada daerah mitra.

\section{KESIMPULAN DAN SARAN}

Kesimpulan dari kegiatan pengabdian kepada masyarakat yang telah dilaksanakan pada desa Tanjung Baik Budi 2017 melalui pelatihan pembuatan gula semut adalah:

1. Semua peserta dari kedua mitra dapat mengetahui ilmu baru terutama teknologi pembuatan gula semut.

2. Peningkatan pengetahuan bagi peserta tentang pengolahan gula merah agar lebih baik terutama bagi pengrajin gula merah.

3. Mitra petani kelapa dapat memanfaatkan nira kelapa dalam pembuatan gula semut sehingga memiliki nilai jual yang tinggi.

4. Hasil monitoring diperoleh peningkatan penyadapan nira dan pembuatan gula cetak serta gula semut.

\section{UCAPAN TERIMA KASIH}

Ucapan terima kasih yang tidak terhingga kami sampaikan kepada DIKTI yang telah mendanai Program IbM ini. Terima kasih juga kami sampaikan kepada UP3KM, Ketua Jurusan Teknologi Pengolahan Hasil Perkebunan, temanteman dosen, mahasiswa dan mitra petani kelapa serta pengrajin gula merah yang telah banyak membantu dan mengsukseskan program tersebut.

Perlu dilakukan kegiatan yang berkelanjutan agar usaha yang dilakukan masyarakat tumbuh dan berkembang dengan baik serta perlu pelatihan sistem manajemen yang baik dalam bidang pemasaran.

\section{DAFTAR PUSTAKA}

Adli, Z.M, 2010. Pemanfaatan Gula Bubuk Aren Sebagai Bahan Pembuatan Permen Anti Diabetes. Mahasiswa Program Tingkat Persiapan Bersama Bogor Agricultural University. Bogor.

Pragita. E.P. 2010. Evaluasi Keragaman dan Penyimpangan Mutu Gula Kelapa Kristal (Gula Semut) Di Kawasan Home Industri Gula Kelapa Kabupaten Banyumas. Jurusan Teknologi
Pertanian. Fakultas Pertanian. Universitas Jenderal Soedirman. Purwokerto

Setiawan, 2014. Gula semut memasuki pasar ekspor. Bappeda. Diakses dari . : :http://www.radarbanyumas.co.id/. Banjarnegara. Diakses tanggal 30 Maret 2016.

Sholikhah. U. 2014. (IbM) Kelompok Usaha Gula Merah Di Kecamatan Semboro Kabupaten Jember. Program Studi Agroteknologi. Fakultas Pertanian. Universitas Jember. Jember.

Wijaya, W. Wigyanto, Hidayat. A. 2011. Perbaikan Kulitas Gula Semut Dari Nira Nipah Dengan Penambahan FCS (Fine Crysal Sucrose). Jurusan Teknologi Industri Pertanian. FTP. Universitas Brawijaya. Malang.

Zuliana S, Endrika W, Wahono HS. 2015. Pembuatan gula semut kelapa (Kajian pH Gula Kelapa dan Konsentrasi Natrium Bikarbonat). Jurnal Pangan dan Agroindustri: 4:109-119. Teknologi Pertanian. Universitas Brawijaya. 